\title{
THE READINESS OF VILLAGE UNIT COOPERATIVE IN FACING ECONOMIC COMPETITION AND GLOBALIZATION
}

\author{
Suratno $^{1}$, Deny Denmar ${ }^{2}$, Bagus Shandy Narmaditya ${ }^{3}$ \\ ${ }^{1}$ Faculty of Faculty of Teacher Training and Education, Universitas Jambi, suratno@unja.ac.id \\ ${ }^{2}$ Faculty of Faculty of Teacher Training and Education, Universitas Jambi, deny_denmar@unja.ac.id \\ ${ }^{3}$ Faculty of Economics, Universitas Negeri Malang, bagus.shandy.fe@um.ac.id
}

\section{DOI}

https://doi.org/10.26740/jupe.v9n3.p96102

\author{
Article history \\ Received \\ 25 June 2021 \\ Revised \\ 5 July 2021 \\ Accepted \\ 7 July 2021
}

\section{How to cite}

Suratno., Denmar, D., \& Narmaditya, B. S. (2021). The Readiness of Village Unit Cooperative in Facing Competition and Globalization. Jurnal Pendidikan Ekonomi (JUPE), 9(3), 96-102. https://doi.org/10.26740/jupe.v9n3.p96102

Kata Kunci: Koperasi unit desa, persaingan usaha, kesejahteraan ekonomi

Keywords: Village unit cooperative, business competition, economic welfare

\section{Corresponding author}

Suratno

suratno@unja.ac.id

\begin{abstract}
Abstrak
Penelitian ini bertujuan untuk mengetahui keberlangsungan Koperasi Unit Desa, pengelolaan, dan persiapannya dalam menghadapi persaingan usaha dan globalisasi. Penelitian ini menggunakan metode kualitatif dengan pendekatan fenomenologi untuk memperoleh pemahaman yang mendalam tentang fenomena tersebut. Tiga Koperasi Unit Desa dilibatkan sebagai subjek penelitian di areal perkebunan kelapa sawit di Kabupaten Muaro Kota Jambi, Indonesia. Temuan menunjukkan bahwa koperasi unit desa telah mampu memberikan kesejahteraan yang lebih baik bagi anggotanya. Kedua, Koperasi Unit Desa belum memiliki rencana bisnis yang lebih maju dan modern untuk bersaing di era saat ini. Sebaliknya, usaha yang dilakukan bersifat monopoli sehingga koperasi unit desa sulit bersaing dengan pihak lain.
\end{abstract}

Abstract
This study aims to investigate the continuance of village unit
cooperative, the management, and preparation in facing business
competition and globalization. This study employed a qualitative method
with a phenomenological approach to gain an understanding of the
phenomenon. Three village unit cooperatives were involved as a
research subject in the area of oil palm plantations in Muaro of Jambi
municipalities. The findings indicate that the village unit cooperative has
been able to provide better prosperity for its members. Second, the
village unit cooperative does not have a more advanced and modern
business plan to compete in the current era. However, the business
undertaken is a monopoly that makes it village unit cooperatives difficult
to compete with other parties.

Abstract

This study aims to investigate the continuance of village unit cooperative, the management, and preparation in facing business competition and globalization. This study employed a qualitative method with a phenomenological approach to gain an understanding of the phenomenon. Three village unit cooperatives were involved as a been able to provide beter prosperity for its members. Second, the village unit cooperative does not have a more advanced and modern business plan to compete in the current era. However, the business to compete with other parties. 
Suratno., Denmar, D., \& Narmaditya, B. S.|The Readiness of Village Unit Cooperative in Facing...

\section{INTRODUCTION}

Village unit cooperative, or well-known as KUD, is an Indonesian business entity aiming to accomplish the welfare among members. The existence of KUD in Indonesia has started in the 1950s called the agricultural cooperative. The issuance of Presidential Instruction Inpres No.4/1973 has changed the cooperative to a new business entity called the village business unit (BUUD), which aims to strengthen the existence of cooperatives in the framework of government programs in food selfsufficiency. The government has provided full support by changing BUUD to KUD since 1984 with Presidential Instruction No.4/1984. KUD has been further strengthened by collaboration with Bank Rakyat Indonesia in channeling credit for agricultural production facilities, marketing of agricultural products, and business activities.

In the global economy, KUD has faced challenges to survive and compete with other financial institutions (Utami et al., 2020). The challenges KUD will be even more significant due to environmental changes that are complex and dynamic. To deal with, Lindbloom (2014) argues that cooperatives' strategy is necessary to apply in cooperative business principles. In other words, the principle of cooperatives must be adapted to the era of economic globalization that requires efficiency and applies the principles of modern business management as a competitive strategy. A preliminary study by Gumbira et al. (2020) suggests that the revitalization model for village unit cooperatives in Indonesia.

Satgar (2007) states that cooperatives in Slovakia and other studies show that it is tough to maintain and advance cooperative business by maintaining the principle of democratic cooperation in decision making. Nilsson (2001) further explained that most cooperatives in Slovakia have failed to maintain and improve the performance of cooperatives that are democratically regulated. The principles change in the ownership of voting rights was abandoned. Modern business management based on business efficiency was run as a path taken to maintain cooperatives. Therefore, there is a need for a greater understanding of what KUD should do to maintain business and not be rolled out as the sacrifice of the current economic globalization. In addition, this study also aims to describe how the KUD prepares itself to compete by maintaining the name of the existing cooperative.

\section{METHOD}

This study adopted a qualitative method combining phenomenology and case studies approach. Through a phenomenological approach, researchers attempt to find the essence of the meaning of the phenomenon of experience experienced by sources of information or informants who can be trusted, maintained the validity and reliability of what they say. The transcendental phenomenology approach was chosen to be applied in this study with the consideration that the researcher will try to study a phenomenon in depth through the procedure, which is to put aside the experience and knowledge of the researcher to understand the experience of the participants. The data analysis is conducted by highlighting the important things to understand the phenomenon of the object under study. This research also adopts a case study approach that examines a particular case, in this case, the KUD plantation in Jambi, in maintaining its business. There are three case study models commonly used in qualitative research, namely: a single instrumental case study that is used to examine a single case; collective case studies that use a variety of cases, various perspectives to understand a particular problem; and finally, the intrinsic case study that focuses on examining the case itself because the case is considered unique. This research uses the first case study model, which is a single instrument case study. The procedures and analysis use purposeful sampling, which is then analyzed which results are used as a basis for drawing conclusions from this study.

\section{RESULTS AND DISCUSSION}

\section{Business and Sustain}

To understand what cooperative village unit (KUD) management does in facing globalization. First, it is necessary to recognize the initial vision of the establishment of the KUD. There are three KUDs that are the subject of this research, namely KUD Balam, KUD Tembesu, and KUD Kolem. The three of them are located in Muaro Jambi Regency. KUD Balam was established in 1978 and was originally called the Balam Village Business Unit and later became the Balam KUD in 1996. KUD's business activities met their glory since partnering with PT. Perkebunan BP and PT. Perkebunan Palm Oil (PKS). The number of members is more than 3000 people, all of whom are plasma farmers from PKS who are the core owners of oil palm plantations. The vision of the KUD is the welfare of cooperative members. The idea is no intention to revise this vision to become more advanced "The cooperative was established to fight for member welfare, not for the welfare of the management. Therefore, the intention to become an administrator must be clean, to fight for the welfare of members, it is not allowed for the wealth of the management. That vision must be maintained at all times."

From the perspective of KUD Kolem, being a KUD administrator is a mandate. This is demonstrated by the implementation of KUD management only carried out by three people. Even so, there are no financial conflicts, the annual meeting (RAT) among members' meetings is conducted on schedule, and the yield of the garden is on 
target. Members considered there were no financial irregularities, as evidenced every time a RAT was held, it was always accepted by members. The cooperative vision as above was also demonstrated by the Tembesu Cooperative, which stated that the establishment of the Tembesu Cooperative expected to improve its members, all of whom were smallholders of oil palm plantations in partnership with PT. Gembiraria. When asked about the cooperative's vision, they state the following "Cooperative ideals are the welfare of members, .... these ideals must be maintained at any time. The management of KUD is also more social in nature, meaning that it does not pursue high salaries for its management. Prosperous member, happy caretaker".

Based on the explanation, it is clearly seen that the vision of cooperatives is the welfare of members. In connection with that, when further asked what their understanding is meant by the welfare of members. The main objectives of oil palm growers who are members of the KUD and partner with PT. Oil palm plantations are: managed gardens, managed fertilizers, handled pest problems, and most importantly, the results of the gardens can be enjoyed by farmers when borrowing money from the KUD can serve, there is no corruption. If all these needs can be served by the cooperative, then the members will be prosperous. This opinion was expressed by all KUD management from the three cooperatives who were the subjects of this study.

The mindset that KUD solely operates for one particular sub-district area turns out to be related to their reluctance to open businesses outside the KUD area. In addition, he acknowledged that they were limited by the capacity of the range of business control over the businesses they managed. This is reflected in the statement of one of the management of KUD Balam as follows "With our current effort, we are satisfied because all KUD members are prosperous, manicured gardens, guaranteed crop fertilization, members' savings and loan needs can be up to 30 million per member, depending on the area of member gardens, can be served even though they have to queue. The turnover of the yields of members' plantations that are served through the KUD each month produces a minimum of 20 billion a month, equivalent to 2 hectares of land per hectare at the price of oil palm when the income falls from 1.5 million to 3 million. Shocked (later) if you open a business again, you will be afraid of not being able to manage it."

The same thing was also experienced by KUD Kolem and KUD Balam, they made oil palm plantations as the main business and savings and loans business to members of the owners of oil palm plantations only. They are reluctant to open businesses outside the KUD work area for fear of not being managed well. They are aware of the span of control they have, are unable to manage larger businesses, and are unable to oversee the running of the business. The three KUDs that are the subject of this study all have a savings and loan business unit. Submission of credit every month is always greater than the ability of KUD to provide funds. Apparently, there was no KUD that wanted to meet its capital needs by borrowing from the banking sector or other financial institutions. KUD expects loan assistance from the government to enlarge their capital, at least, there is a government policy to support it, such as a KUD debt guarantee to increase KUD business capital.

KUD, which is the subject of this study, relies on its main business in the field of oil palm plantations owned by KUD members who partner with PT. Plantations in the vicinity of the KUD work area. Various possibilities can occur that cause the results of KUD members' oil palm plantations to be disrupted, both the risk that can be calculated and the risk that is a disaster. Risks that can be calculated, such as the age of plants that are limited to 25 years, means that after 25 years old, plants are not productive, less profitable, and must be replaced with new plants, members of the KUD call it replanting. If old plants have to be replaced with new plants, and new plants will start producing again after the age of five years, it means that for five years, no garden products are marketed. This has the potential to dim KUD efforts. While the risks that cannot be calculated such as land fires, plant pests, and natural disasters such as fire. Oil palm plants are planted on peatlands that are prone to fire. Potential failures can also occur due to flooding, which can cause plants to die. It could also be a threat of bankruptcy of the KUD effort.

In the case of rejuvenation of plants, the government has a program for that which is limited in number while plants that have to be rejuvenated are very broad. For this reason, the oil palm rejuvenation project is sponsored by the company which is carried out in stages. Plant rejuvenation is capitalized by the company first and will be paid by farmers when the plant is productive again. This means that the loan for rejuvenation and maintenance of plants for five years is borne by the company and will be paid by farmers when their oil palm plants are productive again. From previous exposures, it can be seen that the KUD management in the plantation area in the Muaro Jambi district, at least three KUD who is the subject of this study. First, the vision and objectives of the KUD want to prosper the members who are judged by the sustainability of the plantation business, the economic interests of their owners, which are limited to their respective work areas, and there is no desire to expand the business to other regions. Second, there is no clear effort to develop its business to become a large business because it realizes the capacity of the management and human resources (HR) of 
the cooperative is limited, and there is no clear effort in the development of HR prepared by the KUD. Third, in a partnership effort with the company, there is no concern from the KUD if it is abandoned by the company or other threats, KUD considers that the KUD is very much needed by the company so that whenever the KUD is, there is no concern for it. Because of that, the oil palm plantation business is believed not to be a sacrifice for economic globalization.

\section{Self-Defense Efforts and Efforts to Succeed}

Cooperative business activities in the area of palm oil plantations in partnership with Fresh Fruit Bunches (FFB) palm oil companies in the KUD work area can be seen from the presence of competitors as a monopolist for offering fresh fruit bunches to the company. The company also did the same thing as monopsony for the results of oil palm plantations produced by farmers who partnered through the KUD. With such conditions, the KUD and the company actually interlocked. Benefits for KUD members can be enjoyed in the form of market certainty over the results of FFB. The current FFB prices follow the market prices in accordance with negotiations by farmers and companies under the coordination of the Jambi Provincial Plantation Office. Thus, the price of FFB applies fairly according to negotiations and agreements that vary according to the conditions of the crude palm oil (CPO) market and other conditions that affect it.

Through partnerships, KUD will receive many facilities provided by the company (Hendriani, 2018). For example, facilities in the form of truck driver assistance for the business unit for transporting oil palm plantations are provided by oil palm companies to KUD Kolem. Financial assistance for KUD financial management provided by the company to KUD Balam. The same assistance was given by the palm oil company to the management of the KUD Kolem Jaya. Likewise, the assistance he called an incentive provided by the company to the Tembesu KUD management.

Such conditions make KUD complacent with comfortable conditions for the management and the ranks of the managers. This condition can make sense of satisfaction for KUD management so that it is less challenged to expand the business that embodies the KUD business that is more advanced and modern. The condition of satisfaction experienced by the management of KUD in the three study areas was stated by the management of KUD Balam representing other KUD who stated, "......KUD management is satisfied with this condition. We do not want to enlarge KUD afraid of not being sleepy (unable) to take care of it. Human resources we have limited ability. We can maintain the current condition is also very good.... We KUD active management is satisfied with the current situation, does not want to develop other businesses. Understandably, our human resources are limited in their abilities. Just maintaining the current condition is good, if you want to develop another business, you do not have HR. Afraid of adding business, his hopes were to increase profits, but instead were neglected as a result of bankruptcy and harming the KUD, which we have now rated well."

Based on the previous explanation, it can be seen that there is a sense of satisfaction and comfort felt by KUD, making them so that there is no business plan to enlarge KUD efforts to become more advanced and more modern. This satisfaction is also based on their sense of awareness of the limited human resource capacity, which they assess is still weak. When the researcher asked the management forum discussion, managers of business units, daily management, and PPL (Field Extension Officers) located in KUD Balam about the possibility of making a savings and loan unit into a kind of people's credit bank because of its large market potential and substantial income. KUD farmers are also quite large, with more than 3,000 members. They stated that "We take care of this KUD with the main goal of making members prosperous and the needs of members in the affairs of the garden are fulfilled. If the distribution of plantation products which is paid through the KUD, immediately reaches the members in the right amount and there are no complaints from members, it is good for our members. The Waserda business unit used to be the market ruler in this area, now unable to compete with similar businesses in this area. For us, the most important was to serve the needs of members for their oil palm plantations, such as fertilizers and medicines. For this savings and loan business, I was horrified. Horrified by the fear of extending credit to members because of the habits of members who have been the experience of KUD all this time, save almost do not want to, if not forced to cut off the yield of the garden, borrow happily but when returning forgotten or pretending to forget about their obligations. If the savings and loan unit is to be enlarged, special human resources and strategic business locations must be prepared. We are not yet ready to make this savings and loan business unit even bigger and become barred (it will be a problem later)."

The statement of the head of KUD Balam about the welfare of members and their satisfaction in managing cooperatives is not much different from the KUD Kolem as follows: "The most important members of KUD Kolem are prosperous members. Welfare is achieved if the needs of KUD farmer members are well served. Supply of fertilizers and medicines is available and on time. With the current condition, we, the active management of the KUD, are already happy that all members have received garden income paid through the KUD. Business units that cannot 
satisfy members are savings and loans. The demand is always greater than the ability of KUD to provide funds to lend. We are afraid to borrow from the bank to increase the savings and loan capital. If bad loans are not paid by the borrowers because the yields of the farm are down, we might go into a cell (prison)."

Statements of satisfaction with the business conditions and services provided by cooperatives to members and the lack of active management for business development were also experienced by KUD Tembesu. This was stated in a short manner by one of the management as follows "The condition of our KUD business might be said to be the best yet, but we are satisfied that we have been able to meet all the members needs related to plantations even to the extent that we provide car tires. We have no plans to expand the existing business units, namely regional government and savings and loans. Walk as it was before, later if there are proposals from new members we try."

From the presentation of the statement of the cooperative management and related parties, it is clear that satisfaction with the current KUD condition has made the management satisfied and made it less eager to add and encourage its business units, especially savings and loans, to become large and modern. The condition was quick to feel satisfied and less aggressive in promoting cooperatives. After a discussion with the management and management of the cooperative finally found three main issues facing the KUD today. This issue was never addressed to members of the cooperative and other cooperative management and related parties such as cooperative extension officers who actively assisted them.

Based on the explanation of the results of the study to answer the second problem, this research was synthesized as follows. First, the success of the KUD business is highly dependent on the active management at the time. If the management has an active business or business insight and fought for the progress of the KUD, then the business will progress, and vice versa if the management is only democratically elected without regard to his capacity in doing business, not much is expected by the KUD to advance. Second, KUD management is satisfied if they can serve the needs of members, especially those related to plantation business, both in terms of crop maintenance and payment for garden products. All KUD subjects of this research have been able to realize that goal, so the KUD administrators are satisfied with the implementation of their management, and there is no intention to expand the business even more so that modern business is far from his desire. Lastly, KUD does not have a visionary business plan to make it a modern business because of the limited capacity of the management and is afraid to bear the risk of loss. These three things are related to the management capacity, the suspicion of certain parties to the successful
KUD, and the issue of respect for management who are no longer active (Soetriono et al., 2019).

The aim is to make the KUD members in the three KUDs of the research areas realize by the management (Chaddad \& Cook, 2004). First, the members' needs in terms of maintaining oil palm plants from the care of the garden, harvesting the garden's yield, to the payment of the garden through a partnership effort with the FFB processing company have been well realized. There were no complaints from members who expressed their dissatisfaction with this issue. Secondly, in terms of savings and loan businesses, KUD has also been served well. It is just that there has been no effort to make this business even bigger, in terms of market potential is very open. Third, the partnership with the company has been able to realize mutually beneficial business. The KUD can monopolize the supply of farmer's member farms, as can the company monopolizing demand, both of which interlock in partnership. Determination of the price of garden products is done through a joint pricing mechanism between the company and the KUD facilitated by the Jambi Provincial Plantation Office so that it can be accepted by the KUD representing KUD members as sellers of FFB products and FFB processing companies. This success is considered as an achievement and satisfaction of KUD management and management in realizing the ideals of the cooperative they lead. This is in line with the statement of Beber et al. (2018) that cooperatives are expected to provide benefits and economic benefits for their members. This has been able to be realized by the KUD. Conditions of satisfaction and comfort of KUD management can be realized during the 20 years that KUD partnered with the company. There were no worrisome problems for the continuation of the marketing of palm oil belonging to KUD members and the distribution of estate products in the right amount, on payment, and on time. Rejuvenation of the garden is also no problem because there have been offers from both the government and companies.

Regarding business competition issues and globalization pressures, KUD management from the three research subjects, field operative extension officers, and the Department of Cooperatives, Industry, and Trade of Muaro Jambi Regency believe that the KUD that manages the oil palm plantation business is unlikely to become a financial globalization sacrifice. As shown, the condition of the KUD has been able to realize the welfare of members thanks to the hard work of its management, and its plantation business is difficult to compete with similar businesses. This is in line with Hakelius (2018) that cooperatives that have an active and creative board of directors have clear goals and objectives that will make cooperatives high-performance. In comparison, Novkovic 
Suratno., Denmar, D., \& Narmaditya, B. S.|The Readiness of Village Unit Cooperative in Facing...

(2007) suggested that the management must be active and creative, especially in building a wide business network.

KUD is preparing itself to face business competition, and making its business more advanced is very dependent on the management of the KUD. Based on the presentation of the research results synthesized, there are three things related to it, namely: the capacity of the management and the reluctance to bear the risk, the absence of policy and government assistance in favor of cooperatives, and the issue of appreciation for management who are no longer active. In line with the research findings of Nopiyani and Kristina (2020) that the cooperative went bankrupt because of poor business management, especially business management, productivity, and poor information systems. This is closely related to the capacity of cooperative management in managing cooperatives. Likewise, Lindbloom (2014) argues that the strategy of cooperative managers (and also the management of cooperatives) to overcome global pressure with highly competitive business management in the global market is very necessary to be applied in the principles of cooperative business. This means that in managing a cooperative, it must be managed by people with capacity in terms of business, not only persistence in managing but also the ability and range of control needed to do a successful business.

The existence of rules that KUD administrators are democratically elected and the absence of rules about business capability is a separate issue in maintaining the sustainability of cooperative businesses. Satgar (2007) states cooperatives in Slovakia, and other studies show that it is very difficult to maintain and advance cooperative business by maintaining the principle of democratic cooperation in decision making. Likewise, Nilsson (2001) states that most cooperatives in Slovakia have failed to maintain and improve the performance of cooperatives that are democratically regulated. Correspondingly Beber et al. (2018) concluded that many traditional cooperatives are less efficient in doing business, which in turn has difficulty in maintaining their business, which in turn is thrown out of the market, which is caused by the management capacity in addition to other problems such as lack of government attention and capital difficulties.

In developing a savings and loan business as a potential business unit and promising KUD, management hopes to facilitate funding. The desired assistance is not a free grant or assistance that KUD does not have to return. However, convenience assistance such as policies to help enter formal financial institutions or policies that facilitate access to capital. Such difficulties are also experienced elsewhere, as stated by Hakelius (2018) that the difficulty in developing a business lies in difficulty in obtaining capital resources from cheap sources of funds such as the capital market because, in general, cooperatives cannot enter the capital market.

Business competition in the era of globalization, where businesses without borders, become a business challenge in itself. Business competition means the problem of business efficiency. An efficient company means low cost and therefore able to produce products to sell cheaply. Agusalim and Pohan (2017) state that economic globalization can be beneficial and detrimental to others. At the same time, Novkovic (2007) stated that cooperatives are very threatened with IOF (Investor Owned Funds) companies or public companies implementing modern management systems and high efficiency. The problem of business threats, especially in oil palm plantations, turns out to be overcome through mutually beneficial partnerships, and the possibility of switching partners if not profitable is very open. This means that the KUD can control the problem of business sustainability in the main business.

An unsolved problem for active managers who have devoted themselves to the progress of the cooperative, what will the management get besides the salary. The administrators have sacrificed themselves, but there is no guarantee of themselves being inactive in the KUD. This has not yet been established in clear regulations or regulations in the KUD's Articles of Association. Based on experience, many found cooperatives that have advanced. They then changed their business entities into public companies. Schubert and Niederle (2011) cooperatives can survive and become advanced like the GFM Cooperative, which eventually changes their business in public companies.

\section{CONCLUSION}

This study has identified the KUD strategy in facing the global economy. KUD administrators hold firm in realizing the reasons for the granting of cooperatives, namely the welfare of their members, both relating to first management of oil palm plantations, maintenance, to the distribution of garden products; second in all-around businesses that emphasize meeting the needs of members, and; third in the savings and loan business which are all intended for the welfare of members. The achievement of the cooperative's goals makes the management feel safe and comfortable so that they are reluctant to expand their businesses to become bigger and more modern. In preparing themselves to face business competition in the field of the business partnership, marketing of oil palm plantations is carried out through a partnership that binds both parties, namely the KUD and the FFB processing factory. In comparison, the mechanism for determining the price of FFB is done through deliberations every week between the oil palm growers represented by the KUD management and the FFB 
processing companies facilitated by the Office of the Provincial Plantation Office of Jambi. Thus, there is no problem with determining the price of FFB.

The conclusion deals with the second problem: How does KUD management prepare itself to compete by maintaining the name of cooperatives and increasingly advanced businesses as follows. The competition for oil palm plantations mainly comes from individual farmers who are not members of the KUD membership, and that number is relatively small. Business competition did not occur because the KUD succeeded in arming themselves through a partnership effort that was difficult for competitors to penetrate. To develop a cooperative business to be more advanced, KUD hopes that there will be policies from the government, including access to funding. There are problems relating to the election rules for democratically elected KUD management, one person, one vote. KUD management should be managed by people who understand business, not those who win because of the election. This is one of the reasons why it is difficult to maintain the success of a sustainable business. Appreciation for the performance of the management, especially after they are no longer active, there are no rules, the rights of the administrators with limited achievements are only the ownership of the main savings, mandatory savings, and voluntary savings that they have. KUD administrators hope that there will be an appreciation for their work performance in a certain form (i.e., shares) to increase the enthusiasm of the management of the KUD to further advance the KUD.

\section{REFERENCES}

Agusalim, L., \& Pohan, F. S. (2017). Globalisasi ekonomi dan pengaruhnya terhadap kemiskinan dan ketimpangan pendapatan di Indonesia. In National Conference and Call for Paper Improving Accounting, Management dan Economic Research in Developing Bussiness Sustainability and Economi Growth.

Beber, C. L., Theuvsen, L., \& Otter, V. (2018). Organizational structures and the evolution of dairy cooperatives in Southern Brazil: A life cycle analysis. Journal of Co-Operative Organization and Management, 6(2), 64-77.

Chaddad, F. R., \& Cook, M. L. (2004). Understanding new cooperative models: an ownership-control rights typology. Applied Economic Perspectives and Policy, 26(3), 348-360.

Gumbira, S. W., Handayani, I. G. A. K. R., \& Tedjomurti, K. T. (2019). The Urgency of Presidential Policy to Revitalize and Maintain the Existence of Cooperatives Based on Pancasila. Sriwijaya Law Review, 3(2), 199-224.

Hakelius, K. (2018). Understanding the board of Swedish farmer cooperatives-Cases focusing on board composition and interaction patterns. Journal of Co-operative Organization and Management, 6(2), 45-52.

Hendriani, S. (2018). The role of cooperative development strategy to improving the success of village cooperative (KUD) in Riau Indonesia. International Journal of Law and Management, 60(1), 87-101. https://doi.org/10.1108/IJLMA-11-2016-0132

Lindbloom, J. (2014). From workers' cooperative to hiredlabor farm: Accommodating to global market pressures in Slovak post-socialist agriculture. In Labor Relations in Globalized Food. Emerald Group Publishing Limited pp. 115-141. https://doi.org/10.1108/S1057192220140000020005

Nilsson, J. (2001). Organisational principles for cooperative firms. Scandinavian journal of management, 17(3), 329-356.

Nopiyani, P. E., \& Kristina, K. N. (2020). Analisis Manajemen Kredit Guna Meminimalisir Kredit Bermasalah Pada Kud Tirtha Luhur. ARTHA SATYA DHARMA, 13(1), 105-111.

Novkovic, S. (2007). R\&D, innovation and networking: strategies for cooperative survival. In Cooperative firms in global markets. Emerald Group Publishing Limited. Bingley, pp. 205-232. https://doi.org/10.1016/S0885-3339(06)10008-3

Rufaidah, E. (2017). Pemberdayaan Perekonomian Masyarakat Melalui Koperasi Unit Desa Berbasis Usaha Terbimbing. AKADEMIKA: Jurnal Pemikiran Islam, 22(2), 361-374.

Satgar, V. (2007). Cooperative development and labour solidarity: A neo-Gramscian perspective on the global struggle against neoliberalization. Labour, Capital and Society/Travail, capital et société, 56-79.

Schubert, M. N., \& Niederle, P. A. (2011). A competitividade do cooperativismo de pequeno porte no sistema agroindustrial do leite no oeste catarinense. Revista IDeAS, 5(1), 188-216.

Soetriono, S., Soejono, D., Zahrosa, D. B., Maharani, A. D., \& Hanafie, R. (2019). Strategy and policy for strengthening the agricultural cooperative business in East Java, Indonesia. Journal of Socioeconomics and Development, 2(1), 12-22.

Utami, I. T., Suryani, A. I., \& Nurdin, N. (2020). Pengaruh Kompetensi Terhadap Kinerja Karyawan Koperasi Unit Desa (KUD) Bersama Makmur Desa Srimulyo. J-MAS (Jurnal Manajemen dan Sains), 5(2), 241-243. 